\title{
AN ANAEROBIC-AEROBIC BIOLOGICAL TREATMENT OF WASTEWATER AT THE LOW-PRODUCTIVITY PLANT
}

\author{
${ }^{1}$ Fesik L.A., PhD, Assistant Professor, \\ fesik.50@ukr.net, ORCID: 0000-0001-8551-5158 \\ ${ }^{1}$ Sorokina N.V., PhD, Assistant Professor, \\ nvmail@ukr.net, ORCID: 0000-0002-5109-4700 \\ ${ }^{1}$ Geraskina E.A., PhD., Assistant Professor, \\ poselok@te.net.ua, ORCID: 0000-0002-3308-3776 \\ ${ }^{1}$ Odessa State Academy of Civil Engineering and Architecture \\ 4, Didrichson str., Odessa, 65029, Ukraine \\ ${ }^{2}$ Airapetian T.S., PhD, Assistant Professor, \\ Tamara.Ayraprtyan@kname/edu.ua, ORCID: 0000-0002-8834-5622 \\ ${ }^{2}$ O.M. Beketov National University of Urban Economy in Kharkiv \\ 17, Marshal Bazhanov str., Kharkiv, 61002, Ukraine
}

\begin{abstract}
The urgency of the problem of local biological treatment of domestic wastewater from housing in non-canalized areas with improving the quality of treated wastewater to the level of requirements for discharge into fishery bodies of water is considered.

The analysis of the state of local wastewater treatment is given. Existing technological schemes and methods of local sewage, which are used for sewage treatment, are considered.

The results of theoretical and experimental studies of a complex of a local anaerobic-aerobic biological treatment of domestic wastewater from housing in non-canalized areas at the lowproductivity plants are presented.

The results of theoretical and experimental researches of complex of local anaerobic-aerobic biological purification of domestic wastewater of habitation in non-canalized areas at the lowproductivity plants are given.

On the basis of the analysis of work and embodiment of low-productivity plants, used in home and foreign practice of local treatment of domestic wastewater the expediency of application flowing multistage anaerobic-aerobic biological purification of domestic wastewater with use of communities of attached and free-swimming microorganisms is shown.

The proposed low-productivity plant, which includes a three-stage aerobic biological treatment of anaerobically treated wastewater is described. The use of ruff fillers for the retention of hydrobionts gives the opportunity to clear salvo discharge, rapid restoration of the activity of the ruff fillers (for example, in power outages).

The ruff fillers make it possible to organize an appropriate trophic chain of hydrobionts, which dramatically reduces the amount of excess biomass and the removal of suspensions in treated wastewater.

Using the experiments in laboratory conditions and at real industrial treatment plant of a new design there were received parameters of work of stages of anaerobic and aerobic biological purification, the law of nitrification and denitrification processes, the law of specific speed of oxidation of organic pollution in specific conditions of anaerobic-aerobic technology; the opportunity of reception of quality of treated wastewater at the level of the requirements of the specifications for dump of drains in fishing reservoirs is proved.
\end{abstract}

Keywords: biological treatment, attached microorganisms, nitrification, denitrification, ruff fillers, bioreactor.

Introduction. In difficult environmental conditions there is a tightening of the requirements for the degree of domestic wastewater treatment in a non-canalized territory and there is a need for wastewater treatment in accordance with the regulatory requirements for discharge into fishery ponds. 
In recent years the intensity of housing construction with a high level of improvement, detached buildings such as infectious hospitals, camp sites, small enterprises for processing agricultural products in non-canalized areas has increased. The problem of wastewater treatment from these projects is highlighted. This problem is solved by creating scientifically-based, reliable, compact, low-energy-intensive technological schemes and designs of low-productivity plants.

Analysis of recent publications. Recently, plants for wastewater treatment in non-canalized territories have been used successfully, for example, «BIOTAL». There are involved multistage anaerobic-aerobic biotechnology using free-floating activated sludge, automation equipment, highly efficient imported blowers in «BIOTAL». Unfortunately these low-productivity plants (LPP) have some drawbacks - such important issues are not resolved:

- a volley discharge of highly concentrated wastewater;

- an accumulation of wet deposits and preparing them for disposal;

- internal pumping of sludge mixtures does not guarantee controllability of wastewater treatment processes, creation of anoxic or anaerobic zones without siltation.

The plant of intensive biological treatment of small amounts of wastewater «TOPAS-M» [1] implements effective technological solutions to automatically maintain the concentration of activated sludge in the activation phase and periodic wastewater aeration. As a result of the analysis of the plant, the disadvantages of «TOPAS-M» were revealed:

- the issue of salvo inflow of highly concentrated wastewater has not been resolved;

- the problem of accumulation and disposal of sewage sludge is not solved;

-for deep wastewater treatment underground filtration fields and sand and gravel filters are recommended, they require filtering soils and areas;

-operation of the «BIOTAL» and «TOPAS-M» installations requires a high level of automation and control of the wastewater treatment process, and the presence of highly qualified personnel.

An innovative direction in biological wastewater treatment is «Bioconveyor» [2]. It provides a direct flow of wastewater through the treatment plant. In each individual plant site, an immobilized hydrobiocenosis freely develops and forms in accordance with the conditions: Eh, $\mathrm{pH}$, temperature, composition and amount of wastewater, mass transfer. At the same time, microorganisms are kept in the right place, are not washed out, and the wastewater is purified and moves along them.

Semi-submersible biofilters (disk, drum or rotor, with fillers, tubular, etc.) are widely used [3]. Rotary plants are usually multi-stage. Advantages of bio-disks: compact, have low energy consumption, are simple and reliable in operation, withstand volley inflows of wastewater, during breaks, the possibility of drying the biofilm is excluded. The disadvantages of bio-disks include the negative impact of mechanical overloads on the rotor.

The basis of the "CONTUS» complete factory readiness modular plant [4] is a two-stage biological wastewater treatment scheme with attached microflora on a synthetic foam carrier (polystyrene foam) in combination with anaerobic-aerobic sludge treatment to remove phosphorus. Deep wastewater treatment takes place in a «dry» filter. The quality of treated wastewater meets the requirements of fishery ponds. The disadvantages of the installation «CONTUS» include the following: recirculated sludge from the secondary sump returns to the anaerobic zone, it negatively affects the process of anaerobic wastewater treatment; the issue of regeneration of the foamed carrier of the attached microflora of aeration tanks has not been resolved, the plant parameters for the wastewater treatment steps have not been set.

In LPP «Viyaplast» [5] direct-flow passage of wastewater through anaerobic-aerobic bioreactors with fiber loading of the «Viya» type and contact clarification filter (CCF) with foam filter loading is provided. The process of deep wastewater treatment in (CCF) has been studied in detail, but the technological parameters of the anaerobic-aerobic bioreactors have not been determined, and the issue of fiber loading regeneration has not been resolved either.

Thus, the well-known designs of LPP ensure the standard quality of treated wastewater, but either are not reliable in operation or require the presence of highly qualified personnel. 
For many LPP examined in detail, operation parameters and boundary conditions at different stages of wastewater treatment are not clearly indicated. The issues of receiving wastewater at the LPP with high unevenness in productivities, concentrations, and temperature have not been resolved, which negatively affects the efficiency of wastewater treatment processes in small construction projects.

Therefore, it is urgent to improve existing and develop more effective LPP for biological wastewater treatment.

The efficiency of removing organic contaminants in aeration tanks by biological methods can be significantly increased if, in parallel with suspended biocenosis (activated sludge), a device is provided in the volume of the additional loading structure (nets, fibrous fillers, etc.), on the surface of which a biofilm with a high concentration of microorganisms is formed [6-9].

The proposed LPP has a number of advantages compared to the reviewed treatment plants:

- as a result of preliminary anaerobic wastewater treatment in the septic tank dilution, accumulation and averaging of runoff occurs, the concentration of Synthetic surfactants decreases. Ammonification, the formation of easily oxidizable compounds occurs in the septic tank;

- the use of multi-stage aerobic technology for the treatment of anaerobically treated wastewater using hydrodynamic systems makes it possible to clean volley discharges and quickly restore fillers activity (for example, during power outages);

- the amount of excess biomass and the removal of suspended substances in treated wastewater is reduced;

- LPP does not require constant maintenance.

A three-stage flow-through anaerobic-aerobic biological treatment of domestic wastewater by the community attached to the ruff fillers and free-floating microorganisms, with preliminary anaerobic treatment of sewage in a septic tank is used in the proposed LPP.

The experimental researches were carried out at the Water Supply and Drainage Department of Odessa State Academy of Civil Engineering and Architecture [10-12].

In Fig. 1 is a flow chart of wastewater treatment and sediment removal in an experimental production plant.

The technological scheme of wastewater treatment and sediment removal in an experimental industrial plant is shown in the Fig. 1.

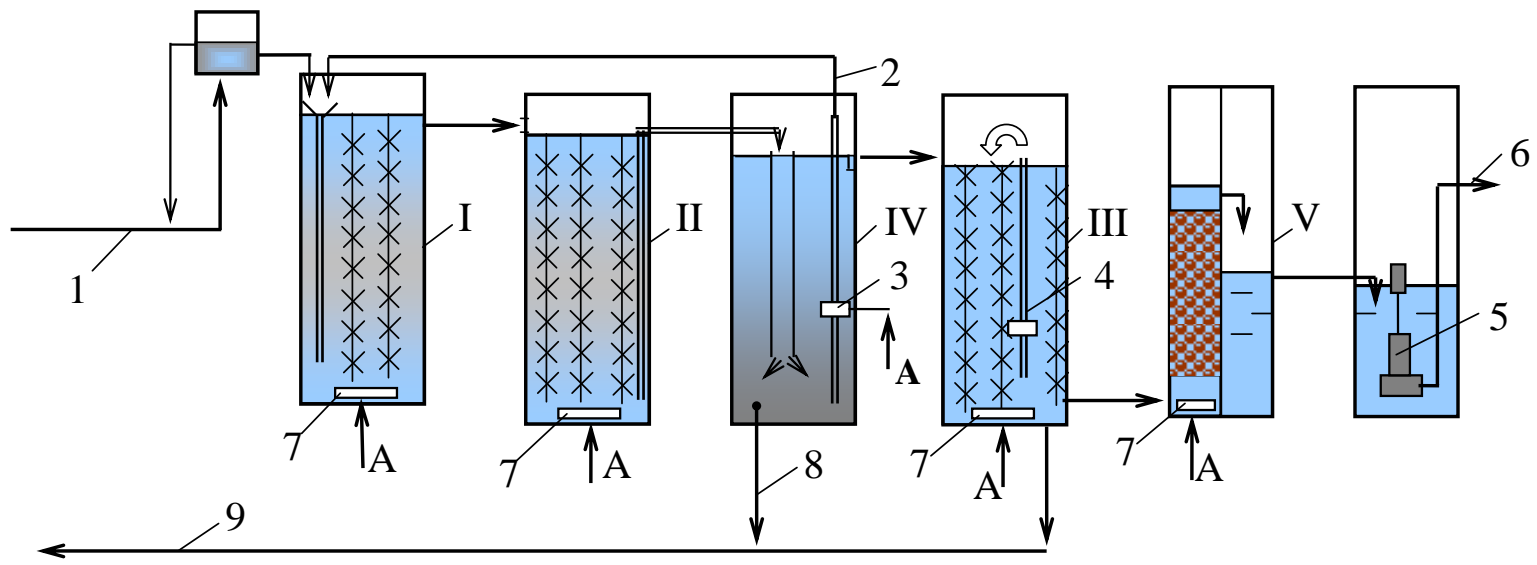

Fig. 1. The technological scheme of wastewater treatment and sediment removal in an experimental industrial plant:

I - denitrifier; II - nitrifier; $\amalg$ - deep treatment bioreactor; IV - secondary sedimentation tank;

V - disinfection filter; A - air; 1 - wastewater of the septic tank; 2 - return sludge pipe; 3 - airlift of return activated sludge; 4 - airlift of circulation in the deep treatment stage; 5 - pump;

6 - pressure pipe of treated wastewater; 7 - bubbler; 8 - excess AS; 9 - regeneration water and excess AS to the septic tank 
In accordance with the technological scheme, the wastewater is introduced into the stage 1 of the bioreactor (denitrifier), mixed with the air supplied by the bubbler 1, and with the return activated sludge coming through the pipe 2 from the secondary sedimentation tank.

The flow of the mixture of return activated sludge and wastewater from the septic tank, rising up the stage 1 , contacts with ruff fillers at the height of the stage. The stages 1,2 and 3 of the bioreactor are equipped with a ruff fillers.

From stage 1, the sludge mixture flows to stage 2 (nitrifier), and then enters the sludge separation into a vertical secondary sedimentation tank. The clarified wastewater enters stage 3 (deep treatment bioreactor). Stage 3 is equipped with airlift 4 of circulation of the deep treated wastewater. At the bottom of stage 3, a bubbler 1 is placed for the regeneration of ruffs. Remove of regenerated water and excess activated sludge (AS) are drained into the septic tank.

From stage 3, the treated wastewater flows into stage 4 - a disinfection filter filled with a granular catalyst filler, which is continuously blown with air and therefore not silted. Disinfected water enters the technical well, from where it is pumped into a water object.

The actual task of improving the efficiency of the proposed LPP is the theoretical justification and the establishment in the course of experimental researches of the optimal parameters of the phased process of a three-stage aerobic biological treatment of anaerobically treated domestic wastewater with a combined biocenosis.

The purpose of the work: scientific substantiation and development of a treatment method and design of a LPP, ensuring the quality of treated domestic wastewater from housing in a noncanalized territory at the level of requirements for discharge into a fishery reservoir.

To achieve this purpose, the following basic tasks were solved:

- determination of the role and the required volume of capacitive structures;

- the establishment of kinetic patterns of growth and vital activity of three biocenoses of various stages of the wastewater treatment process: denitrification, nitrification and deep treatment, bioreactor operation parameters;

- identification of the features of the bioconveyor of a complex of attached and free-floating aerobic microorganisms that treat wastewater anaerobically treated in septic tanks.

Research methodology. The researches were carried out in laboratory and industrial conditions at the pilot and experimental industrial plants (Fig. 1, 2), operating on domestic wastewater at the biological wastewater treatment plant in Odessa.

In the treatment plant at different stages of treatment, anaerobic, anoxic and aerobic conditions were created by a system of aeration bubblers, aeration airlifts and sludge mixture recirculation. In aerobic bioreactors of three treatment stages, ruff fillers were used to hold biocenoses of attached microorganisms. In this case, laboratory researches were performed using optical, physicochemical and biological methods.

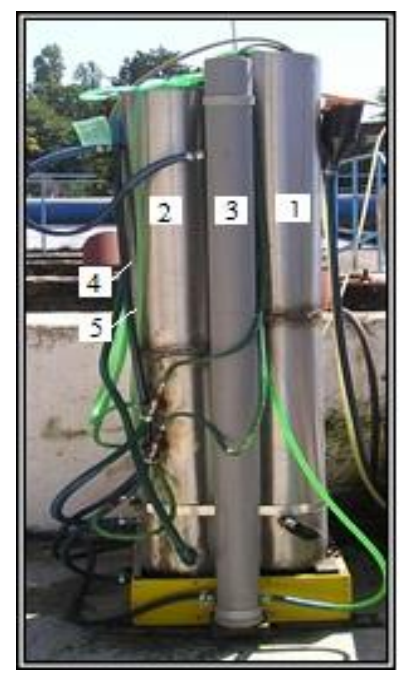

Fig. 2. The experimental industrial plant:

1 - the stage 1 of the bioreactor (denitrifier);

2 - the stage 2 of the bioreactor (nitrifier);

3 - secondary sedimentation tank;

4 - the stage 3 of the bioreactor (deep treatment bioreactor);

5 - the stage of disinfection

Active biomass was evaluated by enzymatic activity. Control over the growth of biocenoses was carried out using samples, segments of a ruff filler $150 \mathrm{~mm}$ long, placed at different points of the bioreactors.

Biocenoses of all treatment stages were evaluated by various types of enzymatic activity. Under the microscope, the mobility of the forms and their diversity were examined. Physicochemical and chemical analysis methods, modern instrumentation technology were used to control the composition of the wastewater. Suspended substances, dry and calcined residue, 
moisture and ash content of the sediment were determined by the gravimetric method. The redox potential, $\mathrm{pH}$ were measured by the polarographic method, as well as using an electrochemical sensor and a portable recording device. Total nitrogen was analyzed by the Kjendahl method, ammonium nitrogen by distillation and subsequent titration, nitrite nitrogen by Griss, nitrogen nitrates by Nessler, BOD by dilution, COD by the bichromate method, gases by chromatographic, organic substances by polarographic, chromatographic and spectrophotometric methods.

The composition of biocenoses working in an experimental plant at different treatment stages was studied using microscopy on a LUMAM instrument.

The research results. The productivity of the experimental industrial plant was set at $2.4 \mathrm{~m}^{3} /$ day. Wastewater anaerobically treated in a septic tank with a flow rate of $100 \mathrm{dm}^{3} / \mathrm{h}$ was uniformly fed into aerobic steps [10]. All steps of aerobic bioreactors had a volume of $112 \mathrm{dm}^{3}$, a working height of $1.82 \mathrm{~m}$ and a diameter of $280 \mathrm{~mm}$. Taking into account the initial concentration of ammonia nitrogen, the circulating flow rate of return activated sludge during commissioning was set at $300 \mathrm{dm}^{3} / \mathrm{h}$.

The stage 1 of the bioreactor. The flow of the sludge mixture was in the stage 1 for no more than 17 minutes. The biomass of microorganisms attached to the ruff fillers was about $220 \mathrm{~g}$. The dose of free-floating activated sludge did not exceed $1 \mathrm{~g} / \mathrm{dm}^{3}$. In the first stage, by adjusting the air supply, the concentration of dissolved oxygen was maintained no more than $1 \mathrm{mg} \mathrm{O} \mathrm{O}_{2} / \mathrm{dm}^{3}$.

The biocenosis of microorganisms of the stage 1 was used to obtain kinetic regularities of the specific rate of oxidation of organic substances according to $\mathrm{BOD}_{20}$ and denitrification of nitrate nitrogen [11].

In Fig. 3 the kinetic dependence of the specific oxidation rate of $\mathrm{BOD}_{20}$ by the biocenosis of the stage 1 of the bioreactor on the concentration of contaminants by $\mathrm{BOD}_{20}$ in the bioreactor is shown. For comparison, the kinetic dependences given by other researchers [1] both for freefloating activated sludge and for the community of attached and free-floating microorganisms working on urban wastewater are shown on the graph.

In Fig. 4 the kinetic dependence of the specific denitrification speed on the concentration of nitrate nitrogen in the bioreactor is shown. For comparison, in fig. 4 the kinetic dependences of denitrification given in the literature [1] for free-floating activated sludge and for the community of attached and free-floating microorganisms operating on urban wastewater are shown too.

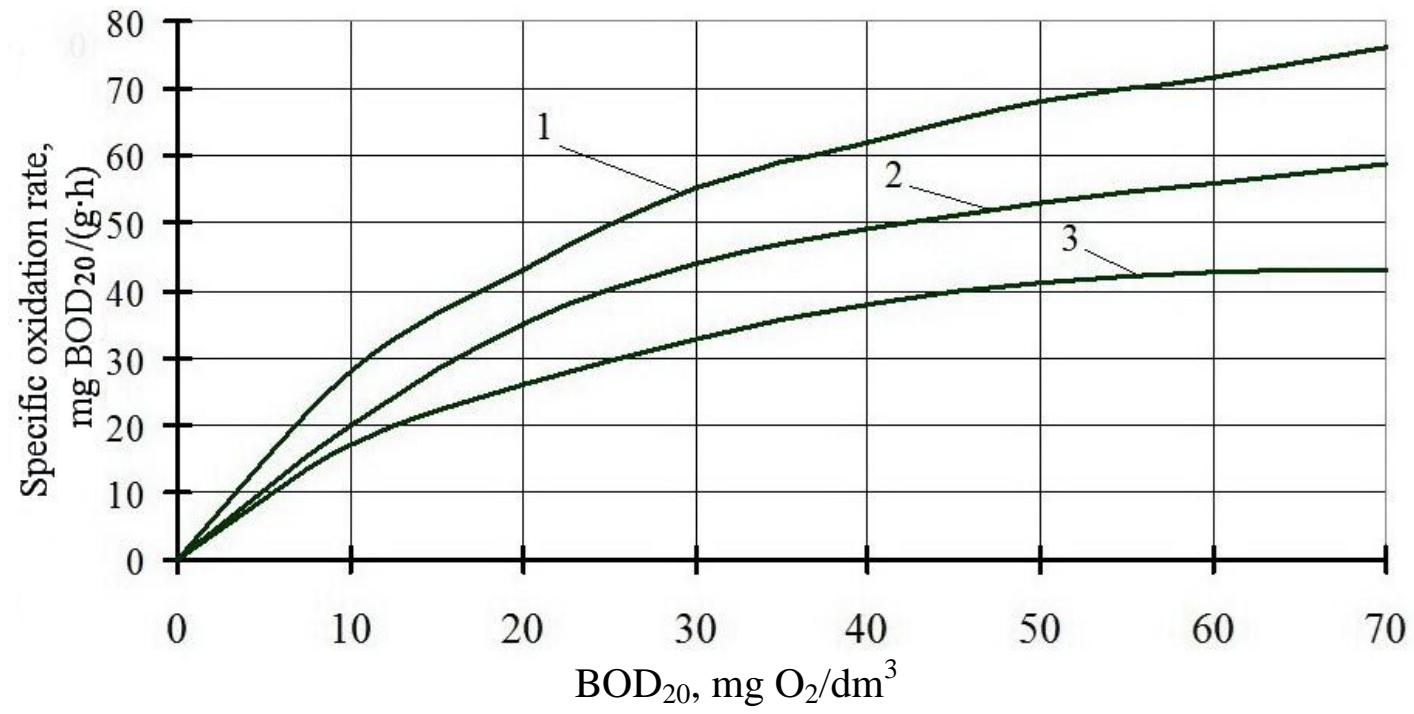

Fig. 3. The kinetic dependence of the specific oxidation rate of $\mathrm{BOD}_{20}$ on the concentration of contaminants by $\mathrm{BOD}_{20}$ :

1 - urban wastewater (community of attached and free-floating microorganisms); 2 - LPP; 3 - urban wastewater (free-floating microorganisms) 
The kinetic dependences of both the specific rate of oxidation of $\mathrm{BOD}_{20}$ and the specific rate of denitrification of a mixture of anaerobically treated wastewater from a septic tank and recirculated sludge mixture are slightly different from the kinetic dependences obtained for a biocenosis treating urban wastewater. This is obviously caused by the presence in the wastewater from the septic tank of an increased amount of reduced compounds that contribute to the acceleration of the denitrification process, but inhibit the oxidation of organic substances, characterized by the $\mathrm{BOD}_{20}$ index.

The stage 1 of aerobic bioreactor provides denitrification of wastewater with a reduction rate of $\mathrm{BOD}_{20}$ of wastewater of about $40 \mathrm{mg} \mathrm{BOD} 20 /(\mathrm{g} \cdot \mathrm{h})$ and a specific denitrification rate of about $6 \mathrm{mg}\left[\mathrm{N}-\mathrm{NO}_{3}^{-}\right] /(\mathrm{g} \cdot \mathrm{h})$.

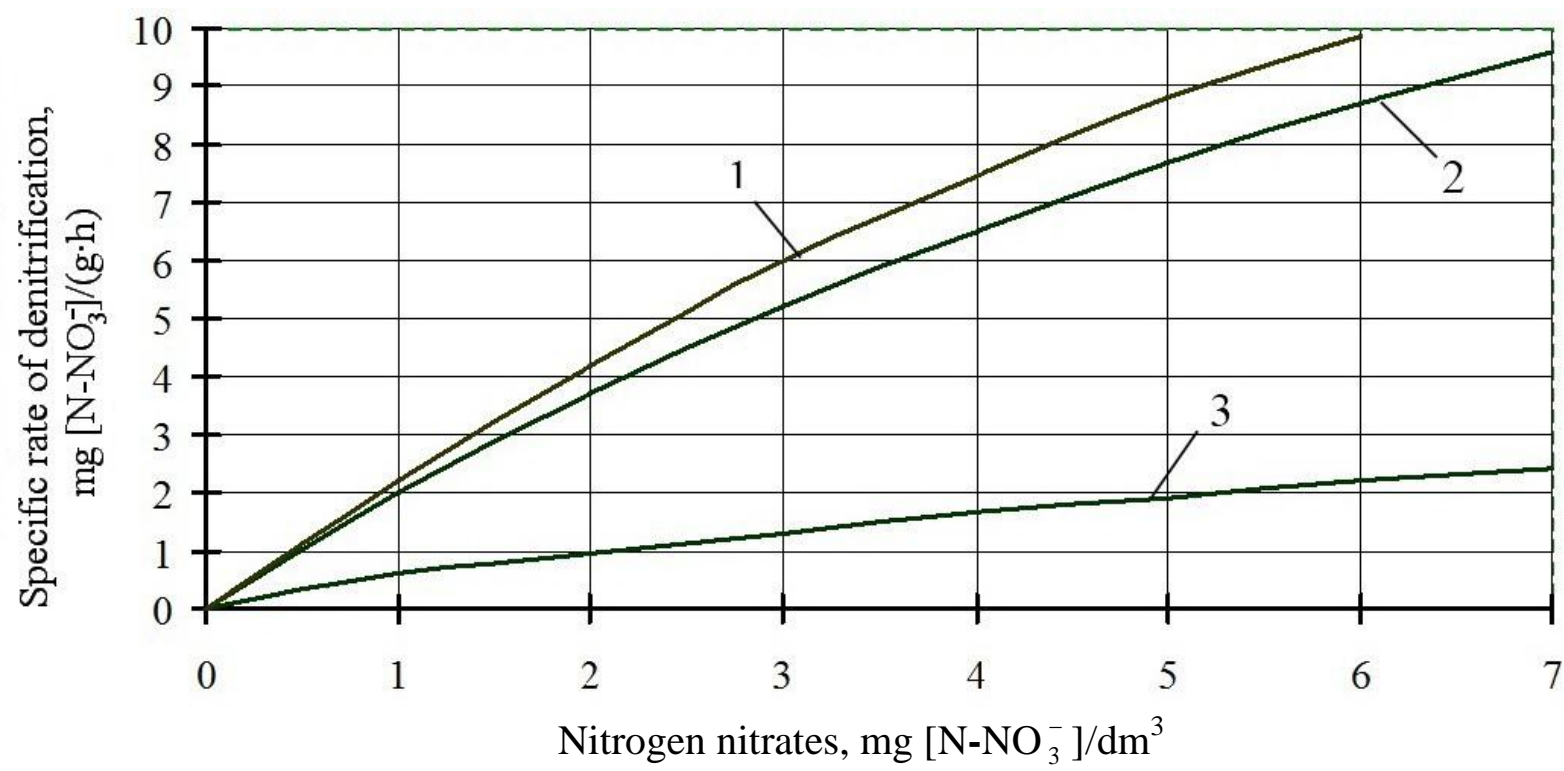

Fig. 4. The kinetic dependence of the specific denitrification rate on the concentration of nitrate nitrogen:

1 - LPP; 2 - urban wastewater (community of attached and free-floating microorganisms); 3 - urban wastewater (free-floating activated sludge)

The stage 2 of the bioreactor. In the stage 2 of the aerobic bioreactor-nitrificator, the attached biomass of nitrifying biocenosis was about $600 \mathrm{~g}$ with a biomass of free-floating activated sludge in the sludge mixture in the nitrifier not more than $100 \mathrm{~g}$, the concentration of dissolved oxygen $3.5-4.0 \mathrm{mg} \mathrm{O} / \mathrm{dm}^{3}$. The residual content of ammonium nitrogen amounted to $0.9 \mathrm{mg}\left[\mathrm{NH}_{4}^{+}\right] / \mathrm{dm}^{3}$ in the sludge mixture leaving the nitrifier.

In Fig. 5 the kinetic dependence of the specific nitrification rate on the concentration of ammonium nitrogen is shown. The specific nitrification rate of ammonium nitrogen did not exceed $2 \mathrm{mg}\left[\mathrm{NH}_{4}^{+}\right] /(\mathrm{g} \cdot \mathrm{h})$, which was almost twice the value of the specific nitrification rate obtained by other authors [1] for free-flowing activated sludge of urban wastewater.

In the experimental-industrial treatment plant a vertical secondary sedimentation tank was used. Since the sludge index of free-floating activated sludge varied in the range of $58-93 \mathrm{~cm}^{3} / \mathrm{g}$, then at an average ascending flow rate of clarified wastewater of $0.5 \mathrm{~mm} / \mathrm{s}$, no problems with the removal of activated sludge were observed.

The stage 3 of the bioreactor. The deep treatment of wastewater was carried out in the stage 3 of the bioreactor by the biocenosis of filtrators-sedimentators held by ruff fillers [12]. The stability of the system was ensured by daily partial regeneration of the ruff fillers with the removal of no more than $20 \%$ of the regeneration mixture into the septic tank. The composition of the deep treated wastewater complies with regulatory requirements for their discharge into a fishery reservoirs. 


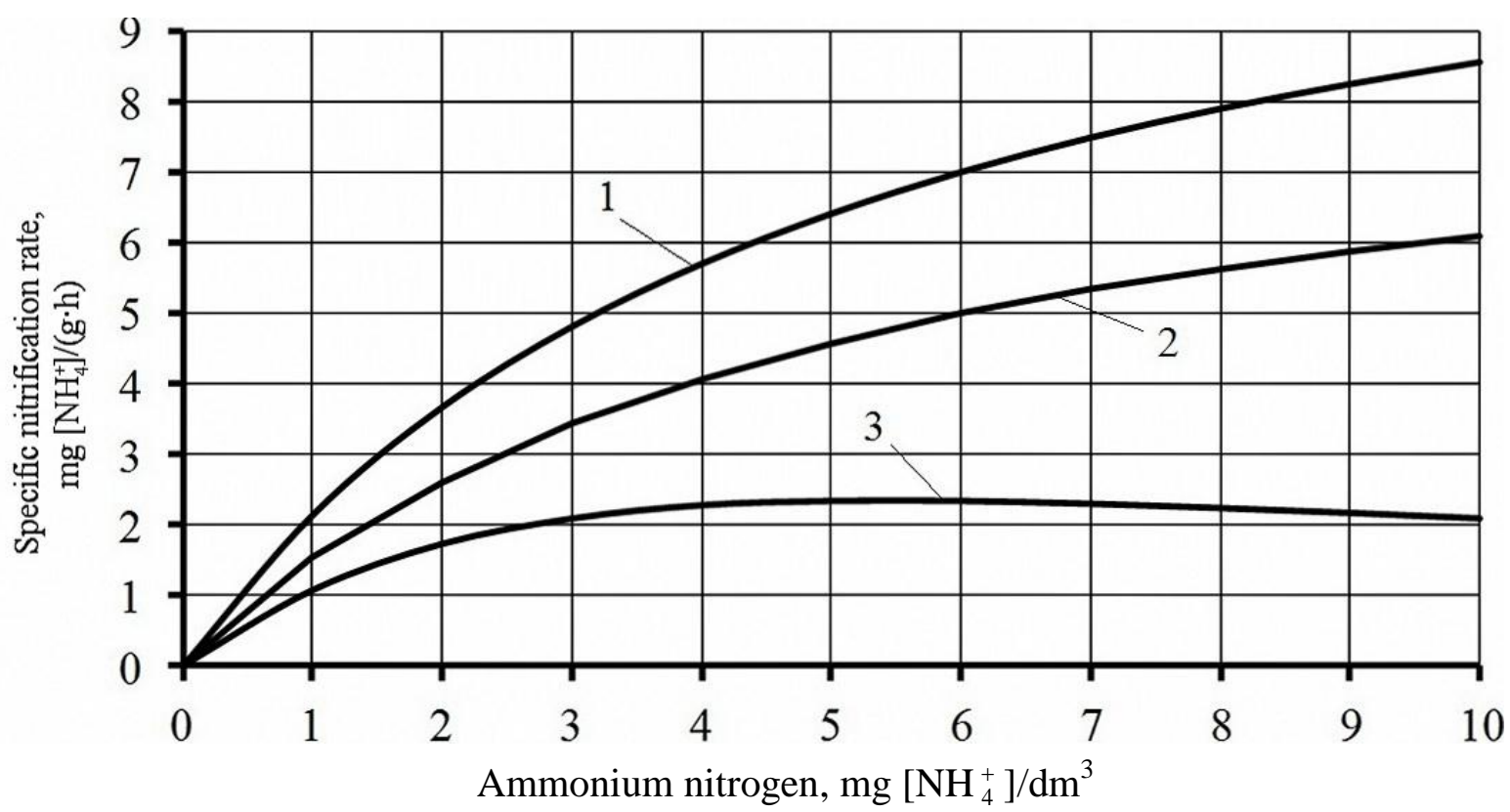

Fig. 5. The kinetic dependence of the specific nitrification rate on the concentration of ammonium nitrogen:

1 - attached microorganisms (LPP); 2 - free-floating activated sludge (LPP);

3 - free-floating activated sludge (urban wastewater)

The empirical dependences of specific rates of organic substances oxidation, denitrification, nitrification [10-11] and biological processes during wastewater treatment [12] were obtained by statistical processing of experimental data. This allows to determine the required amount of biomass of microorganisms and ruff fillers in the stages of wastewater treatment and the volume of the capacitive structures [1].

\section{Conclusions:}

1. The first stage of the aerobic bioreactor provides denitrification of wastewater with a reduction rate of $\mathrm{BOD}_{20}$ of wastewater about $40 \mathrm{mg} \mathrm{BOD}_{20} /(\mathrm{g} \cdot \mathrm{h})$ and a specific denitrification rate of about $6 \mathrm{mg}\left[\mathrm{N}-\mathrm{NO}_{3}^{-}\right] /(\mathrm{g} \cdot \mathrm{h})$.

2. The second stage of the aerobic bioreactor nitrifies ammonium nitrogen to the level of 3-4 $\mathrm{mg}\left[\mathrm{NH}_{4}^{+}\right] / \mathrm{dm}^{3}$ with a specific nitrification rate of at least $2 \mathrm{mg}\left[\mathrm{NH}_{4}^{+}\right] /(\mathrm{g} \cdot \mathrm{h})$.

3. The decisive role in the wastewater treatment processes in the first two stages of the treatment plant is played not by the biocenosis of free-floating activated sludge, but by the biomass of microorganisms attached to ruff fillers.

4. The deep treatment bioreactor ensures the stability of the quality of treated wastewater according to the following indicators: $\mathrm{BOD}_{20}$, suspended substances, ammonium nitrogen and nitrite nitrogen during daily regeneration of the ruff fillers and removal of accumulated suspensions in the septic tank.

5. The objective of further research is to study the effect of temperature on technological process of wastewater treatment in the proposed LPP.

\section{References}

[1] S.M. Epoyan, L.O. Fesik, N.V. Sorokina, Lokal'na ochistka pobutovih stichnih vod v nekanalizovanih rajonah. Monografiya. Odesa, Optimum, 2016.

[2] P.I. Gvozdyak, L.I. Globa, "Nauchnoe obosnovanie, razrabotka i vnedrenie v praktiku novyh biotehnologij ochistki vody", Himiya i tehnologiya vody, T. 20, no. 1, pp. 61-69, 1998. 
[3] M.V. Shuvalov, R.M. Shuvalov, "Rezultaty sravneniya tehnologicheskih pokazatelej pri vybore tipa bioreaktorov dlya ochistki stochnyh vod malyh naselennyh punktov", Vestnik SGASU. Gradostroitelstvo i arhitektura, no. 2, pp. 88-96, 2011.

[4] N.A. Zaletova, S.V. Zaletov, "Modulnaya sistema «KONTUS» dlya ochistki stochnyh vod", Vodosnabzhenie i sanitarnaya tehnika, no. 3, Ch.1, pp. 39-45, 2013.

[5] I.P. Nedashkovskij, A.V. Vasilyuk, "Innovacijna tehnologiya ochistki gospodarskopobutovih stichnih vod na filtrah $\mathrm{z}$ voloknisto-pinoplastovim zavantazhennyam", $\mathrm{Zb}$. nauk. prac VNTU, no. 2 (17), pp. 130-138, 2014.

[6] O.Ya. Olijnik, T.S. Ajrapetyan, "Modelyuvannya ochistki stichnih vod vid organichnih zabrudnen $\mathrm{v}$ biorekatorah-aerotenkah zi zvazhenim (vilnoplavayuchim) i zakriplenim biocenozom", Dopovidi NANU, no. 5, pp. 55-60, 2015.https://doi.org/10.15407/dopovidi 2015.05.055.

[7] O.Ya. Olijnik, T.S. Ajrapetyan, "Praktichni rekomendaciyi do rozrahunku kisnevogo rezhimu pri biologichnomu ochishenni stichnih vod $\mathrm{v}$ aerotenkh $\mathrm{z}$ zakriplenim i zvazhenim biocenozom", Komunalne gospodarstvo mist: nauk.-tehn. zb. HNUMG im. O.M. Beketova, Vol. 1 (147), pp. 175-180, 2019. https://doi.org/10.33042/2522-1809-2019-1-147-175-180.

[8] F. Gebara, "Activated sludge biofilm waste water treatment system", Water Research, Vol. 13, no. 1, pp. 230-288, 1999. https://doi.org/10.1016/S0043-1354(98)00210-3.

[9] O. Wanner, N. Ebert, B. Rittman, "Mathematical modeling biofilm and floc diffusion processes on analytical solution of reaction - diffusion equations", Scientific and Technical report, no. 18, 2006.

[10] N.V. Sorokina, L.A. Fesik, "Ochistka stochnoj zhidkosti v ustanovke maloj proizvoditelnosti", Visnik Odes'koï derzhavnoï akademiï budivnictv ta arhitekturi, Vol. 58, pp. 349-352, 2015.

[11] S.M. Epoyan, N.V. Sorokina, L.O. Fesik, "Nitri-denitrifikaciya stochnyh vod v ustanovke maloj proizvoditelnosti", Naukovij Visnik budivnictva, Vol. 67, pp. 302-305, 2012.

[12] N.V. Sorokina, L.A. Fesik, "Doochistka stochnyh vod v ustanovke maloj proizvoditelnosti", Visnik Odes'koï derzhavnoï akademiï budivnictv ta arhitekturi, Vol. 59, pp. 230-234, 2015.

\title{
АНАЕРОБНО-АЕРОБНА БІОЛОГІЧНА ОЧИСТКА СТІЧНИХ ВОД В УСТАНОВЦІ МАЛОЇ ПРОДУКТИВНОСТІ
}

\author{
${ }^{1}$ Фесік Л.О., к.т.н., доцент, \\ fesik.50@ukr.net, ORCID: 0000-0001-8551-5158 \\ ${ }^{1}$ Сорокіна Н.В., к.т.н., доцент, \\ nvmail@ukr.net, ORCID: 0000-0002-5109-4700 \\ ${ }^{1}$ Гераскіна Е.А., к.Т.н., доцент, \\ poselok@te.net.ua, ORCID: 0000-0002-3308-3776 \\ ${ }^{1}$ Одеська державна академія будівництва та архітектури \\ вул. Дідріхсона, 4, м. Одеса, 65029, Україна \\ ${ }^{2}$ Айрапетян Т.С., к.т.н., доцент, \\ Tamara.Ayraprtyan@kname/edu.ua, ORCID: 0000-0002-8834-5622 \\ ${ }^{2}$ Харківський національний університет міського господарства імені О.М. Бекетова \\ вул. Маршала Бажанова, 17, м. Харків, 61002, Україна
}

Анотація. Розглянуто актуальність проблеми локальної біологічної очистки побутових стічних вод від житла в неканалізованих районах з доведенням якості очищених стічних вод до вимог скидання до водойм рибогосподарського призначення. 
Дан аналіз стану питання локальної очистки побутових стічних вод. Розглянуто існуючі технологічні схеми та методи локальної каналізації, що застосовуються для очистки побутових стічних вод.

Наведено результати теоретичних i експериментальних досліджень комплексу локальної анаеробно-аеробної біологічної очистки побутових стічних вод від житла в неканалізованих районах на установках малої продуктивності (УМП).

На підставі аналізу роботи і конструктивного оформлення УМП, які застосовуються у вітчизняній i зарубіжній практиці локальної очистки побутових стічних вод, показана доцільність застосування проточної багатоступеневої анаеробно-аеробної біологічної очистки побутових стічних вод з використанням спільнот прикріплених і вільноплаваючих мікроорганізмів.

Описана запропонована УМП, що включає трьохстадійну аеробну біологічну очистку анаеробно оброблених стічних вод. Використання йоржів для утримання гідробіонтів дає можливість очистки залпових скидів, швидкого відновлення активності насадки (наприклад, при перебоях електропостачання). Насадки дають можливість організувати відповідний трофічний ланцюг гідробіонтів, що різко знижує кількість надлишкової біомаси і винос суспензій в очищеній стічній воді.

Експериментами в лабораторних умовах і на реальній виробничій очисній установці нової конструкції отримані параметри роботи ступенів анаеробної і аеробної біологічної очистки, закономірності процесів нітрифікації, денітрифікації та питомої швидкості окислення органічних забруднень в специфічних умовах анаеробно-аеробної технології, доведена можливість отримання якості очищеної стічної води на рівні вимог нормативів для скидання стоків до водойм рибогосподарського призначення.

Ключові слова: біологічна очистка, прикріплені і вільноплаваючі мікроорганізми, нітрифікація, денітрифікація, йоржова насадка, біореактор.

\title{
АНАЭРОБНО-АЭРОБНАЯ БИОЛОГИЧЕСКАЯ ОЧИСТКА СТОЧНЫХ ВОД В УСТАНОВКЕ МАЛОЙ ПРОИЗВОДИТЕЛЬНОСТИ
}

\author{
${ }^{1}$ Фесик Л.А., к.т.н., доцент, \\ fesik.50@ukr.net, ORCID: 0000-0001-8551-5158 \\ ${ }^{1}$ Сорокина Н.В., к.т.н., доцент, \\ nvmail@ukr.net, ORCID: 0000-0002-5109-4700 \\ ${ }^{1}$ Гераскина Э.А., к.т.н., доцент, \\ poselok@te.net.ua, ORCID: 0000-0002-3308-3776 \\ ${ }^{1}$ Одесская государственная академия строительства и архитектуры \\ ул. Дидрихсона, 4, г. Одесса, 65029, Украина \\ ${ }^{2}$ Айрапетян Т.С., к.т.н., доцент, \\ Tamara.Ayraprtyan@kname/edu.ua, ORCID: 0000-0002-8834-5622 \\ ${ }^{2}$ Харьковский национальный университет городского хозяйства имени А.Н. Бекетова \\ ул. Маршала Бажанова, 17, г. Харьков, 61002, Украина
}

Аннотация. Рассмотрена актуальность локальной биологической очистки бытовых сточных вод от жилья в неканализованных районах с доведением качества очищенных сточных вод до уровня требований к сбросу в водоемы рыбохозяйственного назначения.

Дан анализ состояния вопроса локальной очистки бытовых сточных вод. Рассмотрены существующие технологические схемы и методы локальной канализации, применяемые для очистки бытовых сточных вод. 
Приведены результаты теоретических и экспериментальных исследований комплекса локальной анаэробно-аэробной биологической очистки бытовых сточных вод от жилья в неканализованных районах на установках малой производительности (УМП).

Отмечено инновационное направление в биологической очистке сточных вод «биоконвейер», предусматривающее прямоточное прохождение сточных вод через очистные сооружения с образованием иммобилизованного гидробиоценоза.

На основании анализа работы и конструктивного оформления УМП, применяемых в отечественной и зарубежной практике локальной очистки бытовых сточных вод показана целесообразность применения проточной многоступенчатой анаэробно-аэробной биологической очистки бытовых сточных вод с использованием сообществ прикрепленных и свободноплавающих микроорганизмов. В качестве носителей прикрепленной биомассы микроорганизмов использованы разнообразные загрузки полупогружных биофильтров, синтетический вспененный носитель (вспененный полистирол), пенопластовая фильтровальная загрузка, волокнистая загрузка типа «Вия».

Описана предлагаемая УМП, включающая трехстадийную аэробную биологическую очистку анаэробно обработанных сточных вод. Использование ершей для удержания гидробионтов дает возможность очистки залповых сбросов, быстрого восстановления активности насадки (например, при перебоях электроснабжения), т.к. прикрепленные микроорганизмы невозможно полностью вымыть потоком жидкости, а многослойность иммобилизованных клеток защищает их от уничтожения при аварийных ситуациях.

Насадки дают возможность организовать соответствующую трофическую цепь гидробионтов, что резко снижает количество избыточной биомассы и вынос взвесей в очищенной сточной воде.

Экспериментами в лабораторных условиях и на реальной производственной очистной установке новой конструкции получены параметры работы ступеней анаэробной и аэробной биологической очистки, закономерности процессов нитрификации, денитрификации и удельной скорости окисления органических загрязнений в специфичных условиях анаэробноаэробной технологии, доказана возможность получения качества очищенной сточной жидкости на уровне требований нормативов для сброса стоков в рыбохозяйственные водоёмы.

Ключевые слова: биологическая очистка, прикрепленные и свободноплавающие микроорганизмы, нитрификация, денитрификация, ершовая насадка, биореактор.

Стаття надійшла до редакції 23.02.2020 